\title{
Disadvantages and Motivation of Consolidated Financial Statements Preparation in Vietnam
}

\author{
Phi Thi Diem Hong ${ }^{1}$, Vu Thi Kim $\mathrm{Anh}^{2} \&$ Manh Dung Tran ${ }^{3}$ \\ ${ }^{1}$ Vietnam National University of Agriculture, Vietnam \\ ${ }^{2}$ Trade Union University, Vietnam \\ ${ }^{3}$ National Economics University, Vietnam \\ Correspondence: Manh Dung Tran, Room No. 202, A14, Living quarter of National Economics University, Hai \\ Ba Trung District, Hanoi, Vietnam. Tel: 0947-120-510. E-mail: tmdungktoan@yahoo.com
}

Received: December 25, 2017

Accepted: January 19, $2018 \quad$ Online Published: January 30, 2018

doi:10.5539/ijef.v10n3p36

URL: https://doi.org/10.5539/ijef.v10n3p36

\begin{abstract}
This study is conducted for investigating disadvantages and motivations of consolidated financial statements (CFSs) with illustration of Vietnamese economic groups. As the requirements of international integration process, the international accounting harmonization contributes to do better the financial information presentation, but how to harmonize successfully is question is not easy to be answered. Data were collected from 15 economic groups in order to have primary data. Then, assumed two key hypotheses to attest the conclusions in early researches. The results show that accounting staffs knowledge as biggest obstacle and legislation as a key motivation of CFSs preparation in Vietnam. The research also finds that the purpose of CFSs is quite difference between different capital owned group types, and the current quality of the CFSs are not still absolutely convincing the users.
\end{abstract}

Keywords: Vietnamese economic group, consolidated financial statements, Vietnam

\section{Introduction}

Keeping up with the tendency of globalization, Vietnam has been efforts in the regulatory reformation to converge its system with the international standards recently (MOF, 2014). Unfortunately, up to now the goals of this renovation have been not yet reached, especially the gap between regulations and its implementation by enterprises still existed. In accounting sector, the significant obstacles to international integration have occurred (Tran, 2013; Phan et al., 2013; Nguyen \& Gong, 2012; Nguyen \& Richard, 2011; Vo \& Le, 2011).

In fact, the current Vietnamese accounting system, with the Accounting Law 2003 (revised 2015) and a system of 26 Vietnamese Accounting Standards (VASs) promulgating in 2001-2005 (based on the international accounting standards - IASs, before 2004), seems stress on the information to the local government and higher authorities rather than investors' ( $\mathrm{Vu}, 2007)$. The updates following IFRS, as the current IASs, are little in the formal existing VAS, even nothing since the first issues. On the other side, the financial reports by enterprises have focused strongly to its initial expectative presentation rather than market requirements. The phenomenon as the investors did not use the information of the financial statements prepared by enterprises for their making decision are not small (Vu, 2007; Nguyen, 2013). In addition, frauds in number on financial statements are not only one but also a number of enterprises (Phuong, 2012). Regarding to CFSs, the dominant reports to provide the financial information that protect the interest of investors, the mismatches among the numbers before and after auditing, even before and after listing in the stock market still occur (Nguyen, T. B. L. \& Nguyen, G. D., 2013). The main reason for these differences is mostly the asymmetric information between inside and outside investors (or the inadequate gap between users and suppliers of reports). Many previous researches support the inconsistence of accounting regulations system as a major cause of these negative conditions in Vietnam.

However, there are a number of reasons outside regulations contributing to this situation. It is probably that not all Vietnamese economic groups submit the CFSs with the unappreciated information in passive way but there are more than two enterprises (data survey) willing to publish another better than their submitted one. This means the attest of early research conclusions relevant to this topic needs to be considered. In order to clarify the current situations and find appropriate recommendations in reducing these mismatches between regulations and 
its implementation, a survey with 15 economic groups was conducted. Then, the research hypotheses are assumed and proved to accept or deny them basing on the primary data. The descriptive statistics are applied to explore research findings, which will then be calculated and analysed. Furthermore, the whole research likes an invaluable reference, in very few English research in the worldwide, even the less is known about the side of practical entity to next studies on Vietnamese accounting.

This research is structured as follows. Section 2 reviews the suitable literature of the topic. Section 3 describes the data sample collection and hypotheses of the research. Section 4 show the results while a discussion of key results is shown in Section 5. Some key conclusions are presented in Section 6.

\section{Literature Review}

Focusing on the CFSs in Vietnam, literature review is conducted for showing the gap that needs to be investigated. The current accounting regulation system, specially consolidated accounting, is set as the basic theory, while the economic group, a group of entities under common control, is defined main respondentto get the real practical case. A comparing among the points between this system and its implementation is background of research findings.

For beginning, this study starts to look for accounting references. In the research worldwide, any references of CFSs were considered. Then they were compacted into the case study of the CFSs in Vietnam. Consequently, a huge pile of documents has been found on consolidated accounting in general and the CFSs in particular. Generally, the CFS theme has been researched on various aspects all over the world for long time. The first CFSs as a present type were developed at the beginning $20^{\text {th }}$ with the prototype of CFSs adopted in the US railway company (Oguri, 2002). Then it was crossed to many others in the world, and the great development in the 1990s (Nobes and Parker, 2000). At first, the consolidated financial reports differ markedly among countries. But they were designed as a single set of high quality, global accounting standards, after 1973 - the International Accounting Standards Committee (IASC) was found. The typical one was the promulgation of IAS 22 (1993)-Business combinations and IAS 27 (1989)-Consolidated financial statement and accounting for investment in subsidiaries. These standards contributed greatly on making perfect of IASs system ongoing as well as issuing IFRSs at the present. After that, many studies of CFSs, including direct or indirect, were conducted to examine their appreciation in the implementation, whereas it only became a revolution theme since 2001 when establishing the IASB to replace the IASC. A short later, in March 2004, the IASB issued IFRS3-Business Combinations (revised 2008) to replace IAS 22, and in May 2011, promulgated the IFRS 10-Consolidated Financial Statements (amended in 2012).

Notably, along to global tendency development, there are more and more academic studies on CFSs have been done. The international convergence or harmonization themes became a great topic in many countries. Unfortunately, from the viewpoint of business firms, we have not found many first -hand researches about CFSs (at least at the time of this study). The theoretical researches were explored as early as in the 1920s, but the first evaluation of CFS preparation was not conducted as the academic reports until 1980s (Phi, 2017). Generally, most researches used primary data through the stock markets or the publications of CFSs by firms, a limited number of studies use the direct approach by business entity. Similarly, this situation has also occurred in Vietnam.

The Vietnamese research on the CFS only appeared beginning in the 2000s and became an attractive theme after the first stages of issuing VASs in 2003, especially when being the participant of WTO in 2007. At the first period of 2000s, they were mentioned mainly in academic training program or graduated theses in universities. Nevertheless, following the time they are discovered in a lot of different aspects. Some of them explored the specific contents which effect directly or indirectly on the CFS presentation, while others focused in large on the consistence or convergence or harmonization of VASs with IFRSs for the CFSs with the higher academy information. For instance, obstacles of current VAS on CFS were mentioned by Mai (2010), Vu (2016), the relationship between the information of CFS and the understanding of user was discovered by Nguyen (2013), the inconsistence of number on the financial reports (including the CFSs) of listed firms was explored by Nguyen and Nguyen (2013), the convergence of VAS with IFRS for the CFSs was studied by Tran (2014), Pham (2015), and so on.

Generally, almost they considered much about the regulation system of accounting. They seemed to be separately on the side of theory; or focused on one or some little respects of the practical side; or conjunction between theory and practical information, majority the secondary data for practical research. This was also a key reason to do this study with a sample survey to look into disadvantages and motivations of CFSs on the side of economic groups in the context of Vietnam. 


\section{Data and Hypotheses}

\subsection{Data Collection}

By the way of "snowballing", the sample was selected through the researcher's own network to lead to another network that received tremendous support of potential interviewees. The phenomenon of survey was defined to be the economic groups under the current accounting regulations in Vietnam. As for this meaning, the target sample of survey did not face any limitation for business industries or the style of owner capital. But it is necessary to present the CFSs. The total number of interviews has expected 15 big economic groups doing business in Vietnam, including 9 Stated groups; 3 private groups, and 3 others. Almost group has the parent company or holding company in Vietnam, the direct managers or chief accountants or accounting staffs in good at the CFSs of group were dominant interviewees of the study. Mainly, one questionnaire presented information for one group as the performance result of survey. The main questions were also divided into two separate sections including general business information and specific accounting majors (also covered the CFSs). It is designed including over 150 criteria setting up in 28 questions. Moreover, in the case of being uncollected reality information (e.g. the interviewee had no answer; or the information that needs collecting goes beyond interviewees' knowledge, etc.), a sub-question was applied in active ways. The time period was predefined to 2014-2015, especially in May, August and December each year when the fiscal year in Vietnam always starts annually on $1^{\text {st }}$ January and ending on $31^{\text {st }}$ December. The pre-survey was conducted as an important step in August 2014, the formal survey started December 2014.

In fact, there are three in tenth current big State groups, one foreign corporation and eleven private groups and State corporations were chosen as presentation on Table 1.

Table 1. Overview of research sample

\begin{tabular}{|c|c|c|c|c|c|}
\hline \multirow{2}{*}{ Criteria } & \multicolumn{2}{|c|}{ Observation } & \multirow{2}{*}{ Criteria } & \multicolumn{2}{|c|}{ Observation } \\
\hline & Quantity & Percent & & Quantity & Percent \\
\hline 1. Ownership & & & 4. Market & & \\
\hline - Foreign organization & 1 & 6.7 & - Input: +Domestic & 6 & 40.0 \\
\hline - State organization & 9 & 60.0 & + Import & 0 & 0 \\
\hline - Private organization & 3 & 20.0 & + Both & 9 & 60.0 \\
\hline - Others ${ }^{(1)}$ & 2 & 13.3 & - Output: + Domestic & 5 & 33.3 \\
\hline Total & 15 & 100 & + Export & 1 & 6.7 \\
\hline 2. Group model & & & + Both & 9 & 60.0 \\
\hline -Parent-subsidiary & 6 & 40.0 & 5. Industrial area & & \\
\hline -Corporation (holding Co.) & 9 & 60.0 & -Telecom & 1 & 6.7 \\
\hline total & 15 & & -Oil and gas & 1 & 6.7 \\
\hline 3. Sectors & & & -Petroleum & 1 & 6.7 \\
\hline - Service & 2 & 13.3 & -Coal and Mineral & 1 & 6.7 \\
\hline - Manufacturing and Trade/Commerce & 4 & 26.7 & -Textile & 2 & 13.3 \\
\hline - Commerce and Service & 3 & 20.0 & -Building & 2 & 13.3 \\
\hline - Manufacturing, Commerce and Service & 6 & 40.0 & - Transportation & 1 & 6.7 \\
\hline Total & 15 & 100 & -Others ${ }^{(2)}$ & 6 & 40.0 \\
\hline
\end{tabular}

Note. (1).:Joint stock Co. after finishing the equitization from the state company; (2). financial service; IT- software; food, security, etc.

The groups' industries were various, including telecoms, transportation, gas and oil, textile, infrastructure, building, investment of property, etc. It is popular each economic group has over 10 subsidiary firms, as many as 67 (Petrolimex group) and as few as 1, respectively. Among the economic groups in survey, there were more than $73 \%$ groups in sample preparing their CFSs at the end of a financial year or monthly, while there was only over $13 \%$ respectively at the date of acquisition. And the same rate (over 13\%) was at both time of fiscal year or monthly and date of acquisition. For the group of preparing CFSs in sample, there were only ten groups organizing separate accounting staffs' group for making CFS purpose. In which most of them designed two staffs in this group among many others in the same accounting department of whole group. 
Table 2. Characteristics of economic groups in CFS preparation

\begin{tabular}{|c|c|c|c|c|c|}
\hline \multirow{2}{*}{ Criterion } & \multicolumn{2}{|c|}{ Observation } & \multirow{2}{*}{ Criterion } & \multicolumn{2}{|c|}{ Observation } \\
\hline & Quantity & Percent (in total) & & Quantity & Percent (in total) \\
\hline \multicolumn{3}{|l|}{ 1. No. of subsidiaries } & \multicolumn{3}{|c|}{ 4. Organize the separate group for making CFSs } \\
\hline - Only 1 & 1 & 6.7 & - Yes & 10 & 66.7 \\
\hline - From 4-5 & 1 & 6.7 & - No & 4 & 26.6 \\
\hline - From 5-10 & 4 & 26.6 & - No information & 1 & 6.7 \\
\hline - Over 10 & 9 & 60.0 & & & \\
\hline Total & 15 & 100 & Total & 15 & 100 \\
\hline \multicolumn{3}{|l|}{ 2. Kind of FS for whole group } & \multicolumn{3}{|l|}{ 5. Prepare CFSs by } \\
\hline -CFSs & 14 & 93.3 & -Self-preparation & 14 & 93.3 \\
\hline - Other ${ }^{(3)}$ & 1 & 6.7 & -Hire the academic service & 1 & 6.7 \\
\hline Total & 15 & & Total & 15 & 100 \\
\hline \multicolumn{3}{|c|}{ 3. When does our group prepare CFSs } & \multicolumn{3}{|c|}{ 6. Number of staffs works for making CFSs ${ }^{(4)}$} \\
\hline a. The date of acquisition & 2 & 13.3 & - Only 1 & 3 & 20.0 \\
\hline b. The fiscal year or monthly & 11 & 73.4 & - Two staffs & 6 & 40.0 \\
\hline \multirow[t]{2}{*}{ c. Both of (a)\&(b) } & 2 & 13.3 & - Three staffs & 1 & 6.7 \\
\hline & & & - No information & 5 & 33.3 \\
\hline Total & 15 & 100 & Total & 15 & 100 \\
\hline
\end{tabular}

Note. (3): Case of foreign organization, wherein their FSs are prepared in purpose for local accounting tax rather than CFSs, CFSs of whole group are prepared by their parent company in foreign country.

(4): Case of economic group (parent company) organizes separately a department for making CFSs.

\subsection{Hypotheses}

Hypothesis 1 (H1): There are significant reasons outside of limitation of accounting legal effect on the presentation of CFSs in Vietnam

A key point sticks on the CFSs is consolidated accounting methods. It is possible to define that the process of consolidation requires the complex techniques which are concerning to the interpretation and judgment records of nature transaction in groups (Kanamori, 2005). In this section, the accounting regulations or accounting policies for consolidation contributes significant role to solve the obstacles in implementation. In purely theoretical sense, the concept of accounting legal framework impacts directly on the practical actions of enterprises (or economic groups) in their presentation of financial reports. It is probably the factors create the expected reports come from other different causes outside the legal system, such as human resources, capital size, traditional culture, and so on.

While nearly all previous researchers supported that the cause of current situation in the CFSs of Vietnamese economic group comes from the existing mismatches of accounting regulations for consolidation. This study concerns that it can be inadequate conclusion without the approaching side of economic groups. This consideration was raise when the author did pre-survey with more than half of total interviewee disagreed that their negative situation came from not only the inconsistence of accounting regulation. Therefore, questions for research were revealed: Have any other causes impact on the present phenomenon of the CFSs in economic groups in Vietnam? What are they? Finding the answers of these questions, study has the first hypothesis (H1).

Hypothesis 2 (H2): the CFSs by economic groups are supplied the financial information for the investors rather than other users in Vietnam

Another point that is quite opposite meaning between the theory and practical aspects relate to the purpose of CFSs in Vietnam. The practical observation reflected the CFSs implementation of Vietnamese economic groups have been limited in order to meet requirements of investors (Hai Bang, 2013; Nguyen, T. B. L. \& Nguyen, G. D., 2013). Typically, it was so difficult for investors to access the information on the financial reports of Vietnamese enterprises, and a number of directors did not use their information (on the financial statement) to make their decision (Vu, 2007). Furthermore, CFSs of Vietnamese economic groups supplied financial information more relevant than other separate financial reports, investors only have used the financial information on the CFSs at the very low level for their decisions (Tran, 2014).

It was believed that the contrast phenomenon occurred in the implementation not for all, however there were more than two concerns about it that means having the seasonable for studying. Therefore, in order to find more 
evidences for agreement or disagreement with the previous researches as well as supplying the material data for next researches relate to the CFSs in Vietnam, this study hypothesized the second hypothesis (H2).

\section{Results}

\subsection{Current Legal Framework and Staffs' Knowledge/Skills Are Most Disadvantages of CFS Preparation}

For the direct question: What are the obstacles to CFS preparation?, the study collected interesting answers from group inside economic as illustrated in Table 3:

Table 3. Obstacles of preparing CFSs in Vietnam

\begin{tabular}{lcc}
\hline \multicolumn{1}{c}{ Obstacles } & \multicolumn{2}{c}{ Observation } \\
\cline { 2 - 3 } & Quantity & Percent $^{(5)}$ \\
\hline 1. Legal framework & 8 & $53.3 \%$ \\
2. Knowledge and skill of staff & 8 & $53.3 \%$ \\
3. Internal management policies & 5 & $33.3 \%$ \\
4. Characteristic of business and industrial area & 7 & $46.7 \%$ \\
5. Others $^{(6)}$ & 6 & $40.0 \%$ \\
\hline
\end{tabular}

Note. (5). Characteristic of financial mechanism for business area by direct management Ministry, view of manager, etc..

(6): Calculated bas on observation of multi-choice question in total number of sample

From Table 3, it is found that the inconsistence of current accounting legislation and staffs' knowledge shortcoming are the two biggest disadvantages of Vietnamese economic groups in CFS preparation with the same rate (53.3\%). Especially, many answerers (46.7\%) claimed to face others obstacles such as the mechanism of financial management, and the managers' knowledge. Although, many groups prepare the CFSs by themselves the most of staffs have not trained in the consolidated accounting, evenly some of them have empty (their group had to hire the service for preparing the CFSs). The accountants took part the respective course (in short time) by the accounting professors or accounting association as the update new regulations. Typically, not at all staffs of accounting department in group, only several accountants (normally 2-3 persons) who are duty in preparing the CFSs were trained.

Table 4. Knowledge of accountants in consolidated accounting

\begin{tabular}{|c|c|c|c|c|c|}
\hline \multirow{2}{*}{ Criteria } & \multicolumn{2}{|c|}{ Observation } & \multirow{2}{*}{ Criteria } & \multicolumn{2}{|c|}{ Observation } \\
\hline & Quantity & Percent & & Quantity & Percent \\
\hline 1. Knowledge of consolidated accountin & & & 3. Type of training & & \\
\hline - Training & 12 & 80.0 & -Update the new regulations & 9 & 75.0 \\
\hline - No training & 3 & 20.0 & - Training for CPA & 1 & 8.3 \\
\hline Total & 15 & 100.0 & - Others ${ }^{(5)}$ & 2 & 16.7 \\
\hline 2. Certified Public Accountant (CPA) & & & 4. Number of staff works to prepare CFSs & & \\
\hline - Non & 11 & 73.3 & - Non-separate group for preparing CFSs & 6 & 40.0 \\
\hline - CPA & 4 & 26.7 & - Separate group for preparing CFSs & 9 & 60.0 \\
\hline+ VNCPA & 3 & & $\checkmark \quad$ Only 1 & 3 & 20.0 \\
\hline + Foreign CPA & 0 & & $\checkmark \quad$ Two staffs & 5 & 33.3 \\
\hline+ Both & 1 & & $\checkmark \quad$ Three staffs & 1 & 6.7 \\
\hline
\end{tabular}

Note. (5). Special courses that group invited directly consultant or auditors or officers to train. The period of special course was from 2 to 3 days

Furthermore, the characteristics of business and internal regulation were also influence on preparation the CFSs. Most groups in sample set up the internal accounting policies for consolidated accounting, whereas all of them adapted the existing regulations under national accounting standards focusing on the bookkeeping technique rather than the accounting. Over $93 \%$ groups of sample regulated in the form of accounting documents and specific accounting methods (for inventory, fix-assets) and nearly $87 \%$ in detailed accounting information. Additionally, less than a half of groups in total had internal accounting policies formed by consulting academic services (auditing and accounting or information technology service). In these groups the accounting software for CFS preparation was quite perfect, whereas some others did not have any separate policies instead of applying directly full current regulations to accounting works. 
Table 5. Internal regulations for consolidated accounting in Vietnamese groups

\begin{tabular}{|c|c|c|}
\hline \multirow{2}{*}{ Criterion } & \multicolumn{2}{|c|}{ Observation } \\
\hline & Quantity & Percent \\
\hline \multicolumn{3}{|l|}{ 1. Documents for building the internal regulations } \\
\hline -Current legal for accounting & 7 & 46.7 \\
\hline -Characteristics of business & 1 & 6.7 \\
\hline -Both & 7 & 46.7 \\
\hline \multicolumn{3}{|l|}{ 2. Main content of internal regulation ${ }^{(7)}$} \\
\hline -Accounting documents & 14 & 93.3 \\
\hline -Time-line for submit & 13 & 86.7 \\
\hline -Accounting method & 14 & 93.3 \\
\hline -Specific information for accounting & 13 & 86.7 \\
\hline -Internal transaction & 12 & 80.0 \\
\hline -Associated and jointly control investment & 11 & 73.3 \\
\hline - Measurement and recognition of NCI & 11 & 73.3 \\
\hline \multicolumn{3}{|l|}{ 3. Setting the internal regulations } \\
\hline -Internal auditing and accounting department & 7 & 46.7 \\
\hline -Internal control department & 1 & 6.7 \\
\hline -Manage board of group & 4 & 26.7 \\
\hline -Both of previous answers & 1 & 6.7 \\
\hline -Others (NGO project, academic service, etc.) & 2 & 13.3 \\
\hline \multicolumn{3}{|l|}{ 4. Kind of legal framework } \\
\hline -Vietnamese accounting system (VAS) & 15 & 100.0 \\
\hline -IASs/IFRSs & 0 & 0.0 \\
\hline \multicolumn{3}{|l|}{ 5. Prepare CFSs by self or hire the academic service } \\
\hline -Hire the academic service & 1 & 6.7 \\
\hline -Self-preparation & 14 & 93.3 \\
\hline
\end{tabular}

Note. (7): Multi-choice question, the proportion was calculated base on the observation in total number of sample

\subsection{Key Motivation by Legislation}

Tables 6 provides information about the main motivation for CFSs to be prepared and submitted by target groups. Preparing CFSs as a must-to-do task is the strongest motivation, while the demands (in single) of investors and managers seem to be ignored. It is noted that most interviewees agree that both of a compulsory job and demands of investors and managers are the main reasons for CFS preparation done by economic groups.

Table 6. Reason of preparing and organization of submit CFSs by Vietnamese groups

\begin{tabular}{lcc}
\hline & Criterion & \multicolumn{2}{c}{ observation } \\
\cline { 2 - 3 } & Quantity & Percent \\
\hline 1. Main reason of preparing CFSs & 5 & 33.3 \\
-Compulsory (by law) & 0 & 0 \\
-Demand of investors & 0 & 0 \\
-Demand of managers & 2 & 13.3 \\
-Compulsory and demand of investor & 1 & 6.7 \\
-Demand of investors and manager & 7 & 46.7 \\
-Both of compulsory and investor and manager's demand & \multicolumn{2}{c}{2} \\
\hline 2. Parent Co or holding Co listed on the security market & 4 & 26.7 \\
-listed company & 11 & 73.3 \\
-non listed company & \multicolumn{2}{c}{86.7} \\
\hline 3. Group has subsidiary as listed company & 13 \\
- Yes & 2 & 13.3 \\
\hline
\end{tabular}

It was noted that, the demand rising from government requirement rather than investors, especially in State groups. The investors and manager boards were two in three agents which hold the biggest portion in submitting 
CFSs by economic groups. However, their submissions demonstrate a great pattern towards the local organizations such as taxation, statistic, auditing or Ministry of Finance rather than only investors or managers. This point is quite different from private groups. Generally, the security office and shareholders are two key organizations of submission by private sector. The details are presented in Table 7.

Table 7. Organization receiving CFSs

\begin{tabular}{lcccccc}
\hline \multirow{2}{*}{ Organization of submit CFSs } & \multicolumn{2}{c}{ Total } & \multicolumn{2}{c}{ State group (9 groups in total) } & Private and other (6 groups in total) \\
\cline { 2 - 7 } & Quantity & Percent & Quantity & Percent & Quantity & Percent \\
\hline -Taxation office & 3 & 20.0 & 2 & 13.3 & 1 & 6.7 \\
-Security Office & 6 & 40.0 & 3 & 20.0 & 3 & 20.0 \\
-Statistic Office & 4 & 26.7 & 3 & 20.0 & 6.7 & 6.7 \\
-Authority office & 1 & 6.7 & 1 & 6.7 & 0 & 0 \\
-financial institution & 1 & 6.7 & 1 & 33.3 & 4 & 0 \\
-Manager board & 9 & 60.0 & 5 & 20.0 & 2 & 26.7 \\
-Bank/creditors & 5 & 33.3 & 3 & 33.3 & 6 & 13.3 \\
-Shareholders & 11 & 73.3 & 5 & 20.0 & 2 & 40.0 \\
-Auditing Office & 5 & 33.3 & 3 & 46.7 & 0 & 13.3 \\
-Ministry of finance & 7 & 46.7 & 7 & 53.3 & 0 & 0 \\
- Direct management units/ministry & 8 & 53.3 & 8 & & 0
\end{tabular}

The respective data from Table 3 to Table 7 shows the $\mathrm{H} 2$ is only consistent with the non-state group while the state group is absolutely inconsistent with $\mathrm{H} 2$. All observations of sample are consistent with H1.

\section{Discussion}

\subsection{CFSs Purpose}

The financial reports dominate with regard to capital market listed companies and multinational enterprises (Zimmerman \& Werner, 2013). This means the capital market is key motivation of CFSs preparation, and the demand of CFSs depend strongly on the power of security market. Unfortunately, the Vietnamese security markets are still very poor and limit reputation in both of the nation and inter-nation worldwide.

Up to the end of April 2015, Vietnam has got more than 650 listed firms (in over $373.212^{[1]}$ enterprises) in two markets of Vietnamese Security (HNX and HOSE). Among the existing listed companies in domestic, there are none of tenth leading groups which have parent company listing whereas it was not difficult to find the famous private groups in opposite position such as Vingroup; FPT; HoaPhat, Vinamilk, etc. Particularly, a significant interviewees of sample mentioned that their business activities relating to consolidation were still simple and non-compliable as the theoretical assumption. Following this view, they have though that the differences between the CFSs and General financial statements (GFS) are only in format or applying units. They have tended to ignore the CFSs preparation or any financial reports for whole group. This also contributed the demand on presentation of the CFSs in groups of Vietnam has been still limit.

Moreover, most of the current biggest economic groups (State owned groups) were established by the government rather than by the market demand. The MOF represents the government to invest and subsidy capital in these groups as an important investor. Under control of this ministry, the Sate-owned groups need to submit directly their financial statements to governmental authorities rather than to investors outside manager boards. Beside the MOF, normally one State-owned group in Vietnam is controlled by its respective ministry, for example: the VN Airline Corporation belongs to Ministry of Transportation; PVN belongs to Ministry of Trade and Industry. Consequently, the Sate-owned groups also submit their CFSs to these ministries compulsorily. Compared with State-owned groups, the private groups, especially listed companies, often face more pressure of the investors. Following this, their CFSs normally are issued to meet requirements from stockholders or security market or directors rather than the government authorities or taxation office.

Generally, almost State groups focus on supplying the CFSs for management units while the private groups has tendency of supplying the CFSs for investors. This means the purpose of the CFSs in Vietnam was still not as the available expectation (following the VAS).

\subsection{Financial Information Quality on CFSs}

The quality of financial statement reflects through the quality of financial information of its presentation. Basing 
on the purpose of financial report, its quality was the level of transparent and comparable information. However, it is unable to be sure all the CFS (after audited) are faithful and accrual presentation, at least in Vietnam. Because many comments from users about the frauds on the CFSs after publishing occurred (Nguyen, T. B. L. \& Nguyen, G. D., 2013). Furthermore, the knowledge and skill of accountants (accounting staffs) as well as managers still lack the respective understanding about the CFSs.

Table 8. Accounting technique for investment

\begin{tabular}{|c|c|c|}
\hline \multirow[t]{2}{*}{ Accounting technique } & \multicolumn{2}{|c|}{ Observation } \\
\hline & Quantity & Percent \\
\hline \multicolumn{3}{|c|}{ 1. Accounting method for investment in subsidiary entities, on the date of acquisition } \\
\hline -The pooling method & 3 & 20.0 \\
\hline -The purchase method & 12 & 80.0 \\
\hline Total & 15 & 100.0 \\
\hline \multicolumn{3}{|c|}{ 2. Accounting method for investment in the associates or jointly control entities, on the date of preparing the CFSs } \\
\hline -The cost method & 3 & 20.0 \\
\hline -The equity method & 8 & 53.3 \\
\hline -Others & 1 & 6.7 \\
\hline -No answer & 3 & 20.0 \\
\hline Total & 15 & 100.0 \\
\hline \multicolumn{3}{|c|}{$\begin{array}{l}\text { 3. On the date of preparing the CFSs, the treat for received earning and profit from the investment in the association and join } \\
\text { stock entities }\end{array}$} \\
\hline -Subtotal entries & 3 & 20.0 \\
\hline -Elimination in full & 1 & 6.7 \\
\hline -Subtotal, elimination and adjustment & 6 & 40.0 \\
\hline -No information & 5 & 33.3 \\
\hline Total & 15 & 100.0 \\
\hline
\end{tabular}

Table 8 shows that, there were significant differences in accounting measurement for the one business action among the groups of sample. The pooling method is not accepted in VAS but at least $20 \%$ applying this method for investment accounting in subsidiary entities on acquisition date. Moreover, The misunderstandings of recognitions between the elimination and adjustment for business combination respectively are popular (especially in goodwill and NCI).The primary data in table 8 and 9 presents also provide a significant number of answer in "No information/no answer" for detail accounting techniques of consolidation. This reflects that the asymmetric knowledge of interviewees in consolidated aspects was one of urgent problems, and the frauds on the CFS of groups have been not reduced, even increased in the case of complex inter-transactions (by reference analysis).

Except for the big auditing organization (Big Four Corporations), there was not any public organization to persuade Vietnamese enterprises (consider around the domestic market) to control the financial information quality of their statements. In the other side, there were not many Vietnamese groups with sufficient financial resources to use the services of Big Four Corporations for their publishing. Therefore, the matter of financial statement quality seemingly does not have any appreciated solutions.

Table 9. Accounting technique for goodwill and NCI

\begin{tabular}{lcc}
\hline \multicolumn{1}{c}{ Accounting technique } & \multicolumn{2}{c}{ Observation } \\
\cline { 2 - 3 } & Quantity & Percent \\
\hline 1. Accounting for goodwill & & \\
1.1. Which contents disclosure for goodwill & & \\
-Long term investment & 2 & 13.3 \\
-Long-term assets & 5 & 33.3 \\
-Operating expense & 2 & 13.3 \\
-Other & 1 & 6.7 \\
- No information & 5 & 33.3 \\
$\quad$ total & 15 & 100.0 \\
\hline
\end{tabular}


1.2. Accounting method for goodwill

-Amortization of historical cost

-Others

-No information

total

$\begin{array}{cc}8 & 53.3 \\ 1 & 6.7 \\ 6 & 40.0 \\ 15 & 100.0\end{array}$

2. Accounting for non-controlling interest (NCI)

2.1. How account for NCI

$\begin{array}{lll}\text {-Following the net value of assets of the acquiree } & 10 & 66.7\end{array}$

-Following the fair value of assets of the acquiree $\quad 3 \quad 20.0$

-Others

-No information

$$
\text { total }
$$

2.2. Accounting method for NCI

- Benchmark method

-Allowance method

-Other

$\begin{array}{cc}12 & 80.0 \\ 0 & 0.0\end{array}$

-No information

total

2.3. Disclosure the NCI on the CFSs

-The equity

-Separate criteria in the equity of the parent entity

\section{Conclusion}

In order to find the special characteristics of the CFSs in Vietnam groups, the study designed the survey with small sample of 15 economic groups to collect data. Using the list of questionnaire with more than 150 different creations relating to prepare and present the CFSs, the primary results focused on proving two hypotheses: H1 related to the obstacles, H2 connected to the purpose of the CFSs in Vietnamese groups. Conjunction with the literature reviews and comparison method, the results of survey supplied the significant to document the research hypotheses. Beside the information that consisted with $\mathrm{H} 1$ and in-consisted with $\mathrm{H} 2$, there were other preliminary conclusions were found as follows:

Firstly, the skill and knowledge of staffs about consolidated accounting has been a big problem to prepare CFS. With the lack of asymmetric accounting technique, the situation the group did not prepare by themselves the CFSs have been occurred.

Secondly, under the strict financial regime (specially in State-owned group), the demand on the CFSs comes from the requirement of legal rather than investors or direct manager. The purpose of CFSs was quite difference between difference of capital owned group types.

Finally, the current quality of the CFSs are still not absolutely convincing the users but it is difficult to find a suitable solution because of no any controlling organization or office.

Although the scope of research area in the data volume and research duration was limit, the study contributed to the preliminary data for the current situation of Vietnamese CFSs, especially in the side of economic groups. Further research on this issue with larger size sample, multiyear dataset and linkage with international accounting conversion is identified and discussed.

\section{References}

Ding, Y., \& Su, X. (2008). Implementation of IFRS in a regulated market. Journal of Accounting and Public Police, 27, 474-479. https://doi.org/10.1016/j.jaccpubpol.2008.09.005

General Statistic Office (GSO). (2014). Statistical Handbook of Vietnam. Statistical Publishing House, March 2015.

Kajiwara, A. (1999). The function of Consolidated Financial Statement in Japan. In S. Sunder, \& H. Yamaji (Eds.), The Book of The Japanese style of business accounting.

Kanamori, E. (2005). The development of Group Accounting in the United Kingdom: Setting the Scene. The 
Ritsumeikan Business Review, XLIII(5), 243-262.

Mai, T. H. M. (2010). Examine the making Consolidated Financial Statements following VAS. Retrieved from http:/quantritaichinh.vn/binh-luan/bai-viet-hach-toan-ke-toan/220-danh-gia-viec-lap-bao-cao-tai-chinh-hop -nhat-theo-quy-dinh-cua-chuan-muc-ke-toan-viet-nam.html

Nguyen, C. P. (2009). Discuss about the methods of consolidating financial statements. Vietnam Accounting Review, $80 . \quad$ Retrieved from http://www.misa.com.vn/tabid/91/newsid/5559/Phuong-phap-hop-nhat-bao-cao-tai-chinh.aspx

Nguyen, C. P., \& Richard, J. (2011). Economic Transition and Accounting System Reform in Vietnam. European Accounting Review (ISI), 20(4), 693-725. https://doi.org/10.1080/09638180.2011.623858

Nguyen, T. A., \& Guangming, G. (2012). Vietnamese Accounting Reform and International Convergence of Vietnamese Accounting Standards. International Journal of Business and Management, 7(10). https://doi.org/10.5539/ijbm.v7n10p26

Nguyen, T. B. L., \& Nguyen, G. D. (2013). Apparent information-the urgent problem of Stock Market in Vietnam. Science of Finance and Accounting Journal, 8(121), 30-33.

Nguyen, V. H. (2013). The information of Consolidated Financial Statement and the understanding of users to make business decision (in Vietnamese). from http://www.ntu.edu.vn/Portals/60/.../v\%20huong.doc

Nobes, C., \& Parker, R. (2000). Comparative International Accounting (6th ed.)..

Oguri, T. (2002). The Genesis and History of Consolidated Financial Statements in USA (pp. 1-265).

Pham, H. H. (2010). De-jure convergence between Vietnamese and International Accounting Standards. Journal of Science and Technology, 5(40), 155-164.

Pham, H. H. (2015). Changing orientation of Vietnamese accounting standards: The viewpoint from the draft of Framework standard. Journal of Economics \& Development, 213, 78-84.

Pham, T. T. H. (2014). The disadvantage and advantage of Vietnamese Accounting standards in preparing consolidated financial Statements. Vietnam Accounting and Auditing Review, 6, 30-33.

Phan, D., Mascitelli, B., \& Barut, M. (2013). Reception of Accounting Professionals towards International Financial Reporting Standards (IFRS) in Developing country: Evidence from Vietnam. In Proceedings of $3^{\text {rd }}$ Global Accounting, Finance and Economics Conference, 5-7 May, 2013, Ryges Melbourne, Australia.

Phi, T. D. H. (2006). Improving the consolidated financial statement of Vietnam Airline group (in Vietnamese) (Master Thesis). Hanoi Commercial University, Vietnam. Under graduated Faculty, 2006.

Phi, T. D. H. (2017). A Comprehensive Study of Accounting System and Consolidated Accounting in Vietnam: Focusing on the factor Analysis of Consolidated Financial Statements (Doctoral thesis). Graduate Division of Commerce, Graduated School, Komazawa University, March 2017.

Phuong, H. (2012). Finding the frauds on the financial statements of enterprises. Retrieved from http://tinnhanhchungkhoan.vn/chung-khoan/bat-loi-sai-sot-trong-bao-cao-tai-chinh-cua-doanh-nghiep-2093 2.html

Tran, H. V. (2014). The convergence between Vietnamese and international accounting for preparation and presentation of the consolidated financial statements: from accounting standards to practical situation (Doctoral thesis). University of Economic Ho Chi Minh City, Graduated Institution. Jan 2014.

Tran, Q. T. (2013). Trend to build Vietnamese financial report standards to satisfy international accounting convergence (Doctor thesis). University of Economics Ho Chi Minh city, Vietnam.

Vo, V. N., \& Le, H. P. (2011). Convergence between Vietnamese and International Accounting Standards: The current situation, causes and oriented development. Vietnam Auditing Review, 12, 25-36.

$\mathrm{Vu}$, D. H. (2016). Consolidated financial statements: Theoretical framework and application in Vietnam. Journal of Economics \& Development, 233(II), 35-42.

$\mathrm{Vu}, \mathrm{X}$. T. (2007). The drawbacks of Accounting practice in Vietnamese enterprises and recommendations. Vietnam Journal of Economic Management, 6(9+10/2007), 54-57, 72-83.

Walker, R. G., \& Mack, J. (1998). The influence of regulation on the Publication of Consolidated Statement. Abacus, 34(1), 48-74. https://doi.org/10.1111/1467-6281.00022 
Whittred, G. (1987). The derived demand for consolidated financial reporting. Journal of Accounting and Economics, 9, 259-285. https://doi.org/10.1016/0165-4101(87)90008-5

Zimmermann, J., \& Werner, J. R. (2013). Regulating Capitalism? The Evolution of Transnational Accounting Governance. Palgrave Macmillan.

\section{Copyrights}

Copyright for this article is retained by the author(s), with first publication rights granted to the journal.

This is an open-access article distributed under the terms and conditions of the Creative Commons Attribution license (http://creativecommons.org/licenses/by/4.0/). 